\title{
Dampak Kualitas Laporan Keuangan, Regulasi Pengendalian Internal dan Keterbatasan Keuangan Terhadap Inefisiensi Investasi
}

\author{
Sansaloni Butar Butar \\ Fakultas Ekonomi dan Bisnis, Universitas Katholik Sugiyapranata \\ Jl. Pawiyatan Luhur IV/1 Bendan Dhuwur, Semarang 50234 \\ Email: sansaloni@unika.ac.id
}

\begin{abstract}
ABSTRAK
Penelitian ini bertujuan untuk menguji inefisiensi investasi pasca diterbitkannya aturan Bapepam-LK tahun 2003 yang mengharuskan direksi membuat pernyataan tertulis bahwa sistem pengendalian internal perusahaan merupakan tanggung jawab mereka. Hasil analisis regresi menunjukkan bahwa pasca terbitnya aturan tentang pengendalian internal kualitas laporan keuangan berhubungan negatif signifikan terhadap inefisiensi investasi. Hasil regresi menunjukkan bahwa tingkat under investment dan over investment perusahaan yang mengalami keterbatasan keuangan dan yang tidak mengalami keterbatasan keuangan tidak berbeda. Secara keseluruhan hasil-hasil temuan di atas memberi isyarat bahwa laporan keuangan berperan penting dalam menurunkan inefisiensi investasi yang bersumber dari over investment dan keterbatasan keuangan tidak berpengaruh terhadap inefisiensi investasi.
\end{abstract}

Kata kunci: Inefisiensi investasi, under/over investment, pengendalian internal, laporan keuangan.

\begin{abstract}
Previous studies have shown that a weak internal control may lead to increased moral hazard and adverse selection and may in turn lead to increased investment inefficiency. This study examine investment efficiency of firms listed on the Indonesian Stock Exchange after the release of Bapepam-LK regulation on internal control in 2003. Regression analysis showed that after the issuance of the regulation on internal control, financial reporting quality is negatively related to investment inefficiency. However, a similar patternt is not detected in under investment gourp of sample. In regard to financial resources constraints, the level of under (over) investment between financialy constrained and unconstrained firms are of no difference. Taken as a whole, the findings support the important role of strong internal control system in reducing investment inefficiency that stems from over investment. In addition, firms'financial constraints do not affect investment inefficiency.
\end{abstract}

Keywords: Investment inefficiency, under/over-investment, internal control, financial statements quality.

\section{PENDAHULUAN}

Laporan keuangan yang berkualitas dapat mengurangi kesenjangan informasi (asimetri informasi) diantara pemangku kepentingan perusahaan seperti yang digambarkan teori keagenan (Watts dan Zimmerman 1986). Jika dibiarkan, kesenjangan informasi memicu konflik kepentingan yang bermuara pada eksploitasi sumber daya perusahaan secara berlebihan. Untuk mencegah timbulmya perilaku oportunistik manajer, teori keagenan menganjurkan perusahaan membentuk mekanisme monitoring yang efektif. Sebagai salah satu mekanisma monitoring, sistem pengendalian internal yang ada dalam perusahaan dibentuk untuk meminimalkan potensi kecurangan yang mungkin terjadi di dalam perusahaan. Hasil studi analitis dan empiris yang dilakukan selama ini menunjukkan bahwa kualitas pelaporan keuangan meningkat seiring dengan meningkatnya 
pengendalian internal perusahaan (Lambert et al. 2007; Ashbaugh-Skaife et al. 2008) dan kualitas laporan yang tinggi meningkatkan efisiensi investasi (Lambert et al. 2007; Biddle et al. 2009). Temuan-temuan tersebut mengisyaratkan bahwa pengendalian internal yang baik mengurangi kesenjangan informasi dan akhirnya meningkatkan efisiensi investasi.

Penelitian ini bertujuan untuk menilai kualitas pengendalian internal pasca terbitnya Peraturan Nomor VIII.G.11 tentang tanggung jawab direksi atas laporan keuangan oleh Badan Pengawas Pasar Modal dan Lembaga Keuangan (Bapepam-LK) pada tahun 2003. Peraturan tersebut mengharuskan direksi perusahaan membuat pernyataan tertulis diatas meterai bahwa sistem pengendalian internal perusahaan merupakan tanggung jawab mereka sepenuhnya. Bila terbukti kelak bahwa laporan keuangan yang diterbitkan perusahaan mengandung informasi atau fakta material yang tidak benar dan adanya informasi atau fakta material yang tidak dicantumkan, sehingga menyebabkan kerugian pada pihakpihak yang mengandalkan laporan keuangan tersebut, maka direksi perusahaan harus bertangung jawab secara hukum.

Peraturan yang diterbitkan oleh BapepamLK ini dapat dipandang sebagai respon otoritas pasar modal Indonesia saat itu atas terbitnya Sarbanes and Oxley Act (SOX) di Amerika Serikat tahun 2002, khususnya Seksi 302 dan Seksi 404. Seksi 302 mengharuskan direksi menyatakan secara tertulis bahwa mereka bertanggung jawab atas laporan keuangan perusahaan, termasuk pengendalian internal, dan setiap perubahan material atas pengendalian internal (Doyle dkk. 2007). Sementara, Seksi 404 mewajibkan manajemen menerbitkan laporan tentang pengendalian internal terhadap pelaporan keuangan yang disertifikasi auditor independen. Berbeda dengan apa yang diwajibkan dalam SOX, khususnya Seksi 404, Peraturan Nomor VIII.G.11 tidak mengharuskan perusahaan membuat laporan khusus tentang pengendalian internal. Bila diperbandingkan, tampak jelas bahwa peraturan yang tertuang dalam Peraturan Nomor VIII.G.11 kurang memberikan pesan yang kuat pentingnya pengendalian internal yang baik untuk meningkatkan kualitas laporan keuangan.

Tidak adanya keharusan bagi perusahaan publik di Indonesia untuk melaporkan keefektifan pengendalian internal yang telah disertifikasi oleh auditor eksternal menimbulkan pertanyaan tentang kualitas pengendalian internal pasca terbitnya peraturan Nomor VIII.G.11 tahun 2003. Pengendalian internal perusahaan mungkin saja tidak mengalami perubahan yang berarti. Namun, ancaman pidana yang mengikuti setiap upaya untuk menyesatkan pengguna laporan keuangan dapat mendorong manajemen perusahaan memberikan perhatian yang serius terhadap pentingnya pengendalian internal yang kuat. Karena itu, penelitian ini mengajukan pertanyaan penelitian sebagai berikut: apakah pengendalian internal perusahaan mengalami peningkatan pasca terbitnya Peraturan Nomor VIII.G.11?

Untuk menjawab pertanyaan tersebut, pengujian dilakukan dengan membandingkan efisiensi investasi yang dilakukan perusahaan sebelum dan setelah terbitnya Peraturan Nomor VIII.G.11 tahun 2003. Seperti dinyatakan sebelumnya, pengendalian internal yang kuat dapat meningkatkan kualitas laporan keuangan dan menurunkan kesenjangan informasi antara pengelola (manajer) dan pemilik modal (pemegang saham). Selanjutnya, kualitas laporan keuangan yang meningkat akan menekan moral hazard dan adverse selection serta mendorong terciptanya keselarasan antara kepentingan manajer dan pemegang saham (Jensen dan Meckling 1976). Bila situasi seperti ini tercipta maka manajer diekspektasi melakukan investasi hanya pada proyek-proyek yang memberikan keuntungan kepada pemegang saham dan tidak lagi berinvestasi secara berlebihan (over investment) atau menunda investasi (under investment) pada proyek yang memiliki positive net present value (Biddle dkk. 2009). Singkatnya, investasi yang dilakukan manajer merupakan investasi yang optimal, dimana over investment dan under investment mengalami penurunan. Biddle dkk. (2009) menyatakan bahwa dorongan manajer melakukan over (under) investment tergantung pada ketersediaan modal (financial resources). Jadi, bila pengendalian internal mengalami peningkatan setelah terbitnya Peraturan Nomor VIII.G.11 tahun 2003, maka dapat diekspekatasi inefisiensi investasi akan menurun. Namun sebaliknya, bila pengendalian internal tidak mengalami perubahan yang signifikan maka inefisiensi investasi tidak mengalami perubahan.

\section{LITERATUR TERDAHULU DAN PENGEMBANGAN HIPOTESIS}

\section{Inefisiensi Investasi dan Pengendalian Inter- nal}

Menurut teori neo-klasik, pengaruh investasi terhadap nilai perusahaan dapat terjadi jika kos marjinal lebih rendah dari manfaat (benefit) marjinal investasi (Abel 1983 dalam Biddle et al. 2009). Perusahaan harus terus melakukan investasi hingga keuntungan marjinal dari investasi modal sama dengan kos marjinal. Keuntungan 
marjinal hanya dapat diperoleh jika perusahaan melakukan investasi pada proyek-proyek yang memiliki net present value yang positif. Dengan berinvestasi pada proyek-proyek tersebut perusahaan meningkatkan nilai perusahaan dan memberikan return bagi investor sebagai penyandang dana.

Kesenjangan informasi (asimetri informasi) antara pengelola dan penyedia dana dapat menyebabkan investasi berjalan tidak optimal (Jensen dan Meckling 1976; Jensen 1986; Blanchard et al. 1994). Penyimpangan terjadi ketika perusahaan secara berlebihan menanam modalnya pada proyek-proyek yang tidak menguntungkan atau yang memberikan negative net present value. Penyimpangan terjadi pula ketika perusahaan tidak melakukan investasi pada proyek yang memberikan positive net present value. Karena itu, Cheng et al. (2013) menyatakan bahwa friksi yang bersumber dari kesenjangan informasi mengakibatkan investasi berjalan tidak efisien.

Menurut teori keagenan, kesenjangan informasi antara pengelola perusahaan (manajer) dan penyedia dana (pemegang saham) mendorong munculnya moral hazard (Jensen dan Meckling 1976; Jensen 1986). Kondisi moral hazard terjadi ketika tindakan manajer tidak mendapat pengawasan yang mamadai. Manajer akan terdorong meningkatkan kesejahteraannya melalui investasi berlebihan (over invesment) pada proyek-proyek yang tidak selaras dengan kepentingan pemegang saham. Manajer juga terdorong mengeksploitasi sumber daya perusahaan dengan membangun fasilitas mewah bagi dirinya atau melakukan investasi pada proyek yang memiliki net present value negatif (Gomariz dan Ballesta 2014; Cheng et al. 2013). Di sisi lain, investor yang rasional mungkin saja mengantisipasi kemungkinan ini dengan menaikkan kos modal. Kos modal yang tinggi menurunkan minat perusahaan untuk mendapatkan pendanaan eksternal, terutama perusahaan yang mengalami keterbatasan keuangan, dan mengurungkan niat berinvestasi pada proyekproyek yang memiliki positive net present value (Lambert et al. 2007). Dengan demikian, efek moral hazard terhadap investasi dipengaruhi oleh keterbatasan keuangan (Biddle et al. 2009)

Kecenderungan manajer berinvestasi terlalu rendah atau terlalu tinggi juga dapat dipicu oleh adverse selection. Sebagai pihak yang paling mengetahui kondisi perusahaan yang sesungguhnya, manajer diekspektasi menjual sekuritas pada saat nilai saham perusahaan dinilai terlalu tinggi (Cheng et al. 2013). Apabila ini terjadi, maka dapat dikatakan bahwa pasar melakukan kesalahan dalam memilih saham yang sebenarnya tidak memiliki prospek yang baik. Situasi seperti ini dikenal dengan istilah adverse selection (Jensen dan Meckling 1976; Jensen 1986). Dana melimpah yang diperoleh dari hasil penjualan yang tidak normal tersebut dapat memicu pengambilan keputusan investasi yang tidak rasional. Manajer terdorong atau bahkan berani melakukan investasi secara berlebihan pada proyek-proyek yang memiliki risiko tinggi. Namun di sisi lain, investor bisa mengantisipasi kemungkinan ini dengan menaikkan kos modal. Kos modal yang tinggi dan tidak tersedianya dana internal yang cukup mendorong manajer mengurungkan niatnya melakukan investasi pada proyek yang memiliki positive net present value (Myers dan Majluf 1984). Jadi, adverse selection dapat mengarah pada terjadinya over (under) investment yang mengarah paada inefisiensi investasi.

Pengendalian internal menjadi sangat penting untuk mengurangi kemungkinan terjadinya inefisiensi investasi. Arens et al. (2012) menyatakan pengendalian internal yang kuat dapat meningkatkan keandalan laporan keuangan. Konsisten dengan pandangan ini, Cheng et al. (2013) menemukan pengendalian internal berpengaruh positif terhadap efisiensi investasi. Sementara, Biddle et al. (2009) dan Gomaris dan Balesta (2014) menemukan laporan keuangan yang berkualitas menurunkan inefisiensi investasi yang bersumber dari under(over) investment .

Lambert et al. (2007) mengembangkan suatu model yang menghubungkan informasi akuntansi dan biaya modal. Pertama-tama mereka membangun model awal menggunakan CAPM dan melakukan penyesuaian dengan mengganti return menjadi arus kas masa depan. Setelah itu mereka menambahkan struktur informasi dengan mengasumsikan laporan akuntansi perusahaan memberikan gambaran yang kabur (noise) tentang arus kas masa depan perusahaan. Mereka memperlihatkan bahwa kualitas informasi akuntansi yang lebih tinggi dapat secara langsung maupun tidak langsung mempengaruhi kos kapital. Informasi akuntansi berpengaruh langsung karena berdampak pada penilaian pelaku pasar terhadap varians dan kovarians arus kas perusahaan dengan perusahaan lain. Sementara itu, informasi akuntansi dapat berpengaruh tidak langsung karena dapat mempengaruhi pengambilan keputusan yang berakibat pada perubahan rasio arus kas masa depan ekspektasian terhadap kovarians arus kas dengan arus kas pasa secara agregat.

Argumen-argumen yang dikemukakan di atas mengisyaratkan pentingnya pengendalian internal yang kuat untuk menjamin efisiensi, keefektifan operasi, ketaatan pada hukum dan regulasi. Sebaliknya, pengendalian internal yang 
lemah dapat memicu pemakaian sumber daya secara berlebihan dan tidak bertanggung jawab oleh pengelola perusahaan. Untuk menutupi perilaku oportunistis tersebut, manajer terdorong menggunakan diskresi yang dimilikinya untuk menampilkan angka-angka yang tidak mencerminkan realitas eonomi perusahaan. Jika ini terjadi, laporan keuangan yang diterbitkan tidak lagi bermanfaat untuk menilai prospek perusahaan ke depan dan memiliki kualitas rendah. Selanjutnya, kualitas laporan keuangan yang rendah mendorong terjadinya under (over) investment. Hubungan antara kualitas laporan keuangan dan inefisiensi investasi yang diakibatkan oleh under (over) investment dinyatakan sebagai berikut:

H1: Kualitas laporan keuangan berhubungan negatif dengan inefisiensi investasi

H1a: Kualitas laporan keuangan berhubungan negatif dengan over investment.

H1b: Kualitas laporan keuangan berhubungan negatif dengan under investment.

\section{Regulasi pengendalian internal dan Inefi- siensi Investasi.}

Feng et al. (2009) mengulas hasil-hasil penelitian terdahulu tentang hubungan kualitas laporan keuangan dan pengendalian internal dengan kesimpulan bahwa pada awalnya pengendalian internal lebih bersifat deskriptif dan belakangan menekankan pengaruh pengendalian internal terhadap harga saham, kos kapital dan kos audit. Hasil ulasan mereka juga menunjukkan bahwa perusahaan yang memiliki pengendalian internal yang lemah cenderung memiliki ukuran yang lebih kecil, kurang menguntungkan, lebih kompleks dan sedang mengalami perubahan yang cepat.

Altamuro dan Beatty (2010) menguji pengaruh peraturan yang mengharuskan bank dibawah Federal Deposit Insurance Corporation di Amerika Serikat melaporkan setiap tahun tanggung jawab manajemen atas laporan keuangan dan pengendalian internal. Mereka menemukan bahwa setelah aturan-aturan yang mengharuskan perusahaan meningkatkan kualitas pengendalian internal terbit, manajemen laba mengalami penurunan dan persistensi laba mengalami peningkatan.

Cheng et al. (2013) menguji perilaku investasi perusahaan-perusahan yang mengungkapkan kelemahan pengendalian internal seperti yang diwajibkan Sarbanes-Oxley Act (SOX). Mereka memisahkan perusahaan berdasarkan keterbatasan sumber keuangan dan menemukan bahwa, sebelum perusahaan mengungkapkan kelemahan pengendalian internal, perusahaan yang memiliki kendala keuangan cenderung melakukan underinvestmen dan perusahaan yang tidak mengalami kendala keuangan cenderung melakukan overinvestment.

Sebagai respon terbitnya SOX di Amerika Serikat, badan pengawas pasar modal Indonesia menerbitkan Peraturan Nomor VIII.G.11 (selanjutnya disebut dengan Regulasi Bapepam-LK) pada tahun 2003 yang menetapkan bahwa sistem pengendalian internal perusahaan merupakan tanggung jawab direksi perusahaan dan harus dinyatakan secara tertulis di dalam laporan keuangan. Direksi perusahaan harus mempertanggungjawabkan secara hukum, apabila di kemudian hari terbukti bahwa laporan keuangan tidak menggambarkan secara wajar kondisi keuangan perusahaan yang menyebabkan investor menanggung kerugian finansial yang besar. Mekanisma pengawasan internal yang ada dalam perusahaan seperti dewan komisaris dan komite audit harus berperan efektif dalam melakukan fungsi pengawasan.

Sebelum Regulasi Bapepam-LK terbit, sistem pengawasan terhadap manajer perusahaan diekspektasi belum berjalan optimal. Hal ini dapat terlihat dari beberapa kasus manipulasi yang terjadi di Indonesia, salah satu yang menarik perhatian publik adalah kasus manipulasi laporan keuangan yang dilakukan oleh Bank Lippo pada tahun 2002. Hasil penyelidikan yang dilakukan oleh Bapepam-LK pada saat itu menunjukkan adanya upaya direksi perusahaan Bank Lippo melalukan praktik manajemen laba dengan mengubah estimasi nilai agunan nasabah dan penyisihan penghapusan aset produktif. Pengendalian internal yang lemah menciptakan peluang bagi manajer untuk mempengaruhi pelaporan keuangan dengan menampilkan angka-angka laporan keuangan yang tidak menggambarkan realitas ekonomi perusahaan. Segala upaya yang dilakukan manajer untuk mempercantik laporan keuangan mendorong terjadinya kesenjangan informasi. Kesenjangan informasi memicu munculnya moral hazard dan adverse selection yang pada gilirannya mendorong terjadinya inefisiensi investasi. Singkatnya, sebelum Regulasi Bapepam-LK terbit, pengendalian internal yang lemah menyebabkan investasi perusahaan tidak dilakukan dengan optimal.

Setelah Regulasi Bapepam-LK terbit tahun 2003, perusahaan-perusahaan publik diharapkan memperbaiki sistem pengendalian internal untuk mencegah manipulasi dan penyalahgunaan wewenang yang dilakukan direksi perusahaan. Bila sebelumnya manajer tidak memberi perhatian yang serius terhadap pengendalian internal, saat ini mereka bertanggung jawab penuh untuk 
menciptakan pengendalian internal yang kuat. Manajer harus mempertimbangkan risiko hukum yang mungkin dihadapi bila dengan sengaja memanipulasi transaksi atau memilih metoda akuntansi yang dapat berpengaruh negatif terhadap kepentingan para pemegang saham. Apabila kualitas laporan keuangan meningkat pasca terbitnya Regulasi Bapepam-LK, maka asimetri informasi diekspektasi menurun. Menurunnya asimetri informasi akan menurunkan moral hazard dan adverse selection dan akhirnya dapat menekan inefisiensi investasi.

Berdasarkan argumen konseptual di atas, hubungan antara kualitas laporan keuangan setelah Regulasi Bapepam-LK terbit dan inefisiensi investasi dinyatakan dalam hipotesis berikut ini:

H2: Hubungan antara kualitas laporan keuangan dan inefisiensi investasi lebih kuat setelah regulasi pengendalian internal terbit tahun 2003.

H2a: Hubungan antara kualitas laporan keuangan dan over investment lebih kuat setelah regulasi pengendalian internal terbit tahun 2003.

H2b: Hubungan antara kualitas laporan keuangan dan under investment lebih kuat setelah regulasi pengendalian internal terbit tahun 2003.

\section{Sumber Keuangan dan Tingkat Investasi}

Seperti yang telah dijelaskan sebelumnya, penyimpangan investasi dari tingkat yang optimal dapat terjadi dalam bentuk under investment dan over investment. Pasca regulasi Bapepam-LK terbit, kualitas laporan keuangan perusahaan diekspektasi meningkat karena adanya perubahan signifikan berkaitan dengan kualitas pengendalian internal. Dengan meningkatnya kualitas laporan keuangan, kesenjangan informasi antara manajer dan investor diekspektasi menurun dan selanjutnya menurunkan adverse selection. Kesenjangan informasi yang semakin kecil mendorong harga pasar saham menuju nilai sebenarnya (intrinsik) karena memperkecil kemungkinan harga saham dinilai terlalu rendah (underpriced) atau terlalu tinggi (overpriced). Kondisi ini menurunkan kecenderungan manajer melakukan over investment.

Di sisi lain, investor yang percaya bahwa laporan keuangan perusahaan menggambarkan kondisi ekonomi yang sesungguhnya memperbaiki penilaian mereka tentang tingkat risiko perusahaan dan bersedia menawarkan biaya modal yang lebih rendah. Perusahaan yang tadinya mengalami kesulitan pendanaan kini memperoleh kesempatan mendapatkan tambahan modal karena biaya modal lebih rendah. Situasi ini akan berdampak pada menurunnya under investment. Argumen ini didukung oleh temuan Cheng et al. (2013) yang menunjukkan bahwa penyimpangan investasi dari nilai optimal dipengaruhi oleh ketersediaan sumber keuangan (financial resources). Lebih jauh mereka menemukan bahwa perusahaan yang memiliki sumber keuangan yang melimpah cenderung melakukan investasi secara berlebihan (over investment). Sebaliknya, perusahaan yang memiliki sumber keuangan yang terbatas cenderung melakukan under investment. Jadi, penurunan inefisiensi investasi menyusul meningkatnya kualitas laporan keuangan lebih terasa pada perusahaan yang mengalami keterbatasan keuangan.

Berdasarkan argumen konseptual dan temuan empiris di atas, hubungan antara kondisi keuangan perusahaan dan inefisiensi investasi sebelum dan setelah Regulasi Bapepam-LK dinyatakan dalam hipotesis berikut ini:

H3a: Perusahaan yang memiliki keterbatasan keuangan melakukan over investment yang lebih kecil setelah regulasi pengendalian internal terbit tahun 2003.

H3b: Perusahaan yang memiliki keterbatasan keuangan melakukan under investment yang lebih kecil setelah regulasi pengendalian internal terbit tahun 2003.

\section{METODE PENELITIAN}

Model yang digunakan untuk menguji pengaruh kualitas laporan keuangan terhadap inefisiensi investasi, under investment dan over investment $\left(\mathrm{H}_{1}, \mathrm{H}_{1 \mathrm{a}}\right.$ dan $\left.\mathrm{H}_{1 \mathrm{~b}}\right)$ adalah sebagai berikut:

IneffInvi,t $=\beta_{0}+\beta_{1} \mathrm{KL}_{\mathrm{i}, \mathrm{t}}+\beta_{2} \mathrm{KaS}_{\mathrm{i}, \mathrm{t}}+\beta_{3}$ Dari, $_{\mathrm{i}, \mathrm{t}}+$ $\beta_{4}$ Tang $_{i, t}+\beta_{5}$ Rugi $_{i, t}+\beta_{6}$ Dkom $_{i, t}+$ Keterangan: $B_{7}$ Size $_{i, t}+\mu_{i, t}$

IneffInvi,t = inefisiensi investasi merupakan nilai absolut residual dari regresi yang menghubungkan partumbuhan penjualan dan investasi;

KLP $=$ kualitas laporan keuangan yang diukur dengan akrual diskresioner dan diestimasi menggunakan empat model berbeda (model Jones, Model Modified Jones, Model Ball dan Shivakumar dan Model Kasznik)

Kas $=$ saldo kas yang dimiliki perusahaan;

Dar $\quad=$ rasio utang terhadap aset;

$=$ rasio aset berwujud terhadap aset total;

Rugi = variabel dummy, 1 jika laba negatif dan 0 jika lainnya;

Dkom = proporsi dewan komisaris independen yang berada dalam dewan komisaris;

Size $\quad=$ ukuran perusahaan yang diukur dengan log aset total. 
Hipotesis H1 memprediksi bahwa laporan keuangan yang berkualitas menurunkan inefisiensi investasi. Jadi, koefisien $\beta_{1}$ diekspektasi bernilai negatif. Model yang digunakan menguji hipotesis $\mathrm{H}_{1 \mathrm{a}}$ dan $\mathrm{H}_{1 \mathrm{~b}}$ hampir sama dengan model pengujian hipotesis $\mathrm{H}_{1}$, kecuali bahawa variabel dependen dalam persamaan (1) diganti dengan variabel under investment atau over investmentt. Hipotesis H1a dan H1b memprediksi kualitas laporan keuangan berhubungan negatif dengan under (over) investment. Jadi, koefisien $\beta_{1}$ juga diekspektasi bernilai negatif. Variabel-variabel lain yang ada dalam persamaan (1) merupakan variabel kontrol seperti yang digunakan dalam Biddle et al. (2009) dan Gomaris dan Balesta (2014). Analisis regresi berganda untuk menguji $\mathrm{H} 1, \mathrm{H} 1 \mathrm{a}$ dan $\mathrm{H} 1 \mathrm{~b}$ dilakukan terhadap observasi yang diperoleh dari tahun 2001-2007.

Seperti dijelaskan sebelumnya, fokus penelitian ini adalah menguji dampak regulasi pengendalian internal yang diberlakukan tahun 2003 terhadap hubungan antara kualitas laporan keuangan dan inefisiensi investasi (under investment dan over investment). Dampak regulasi pengendalian internal terhadap inefisiensi investasi tercermin dalam hipotesis $\mathrm{H} 2$, $\mathrm{H} 2 \mathrm{a}$ dan $\mathrm{H} 2 \mathrm{~b}$. Hipotesis-hipotesis ini diuji dengan menambahkan variabel interaksi KLP*Rule ke dalam persamaan (1). Variabel Rule merupakan variabel dummy yang bernilai 1 jika observasi berasal dari tahun 2003-2007 dan 0 jika berasal dari tahun 20012002. Model yang digunakan selengkapnya adalah sebagai berikut:

IneffInv $_{i, t}=\beta_{0}+\beta_{1} \mathrm{KLP}_{\mathrm{i}, \mathrm{t}}+\beta_{2}$ Rule $_{\mathrm{i}, \mathrm{t}}+\beta_{3} \mathrm{KLP}^{*}$ Rule $_{\mathrm{i}, \mathrm{t}}$ $+\beta_{4} \mathrm{Kasi}_{\mathrm{i}, \mathrm{t}}+\beta_{5} \mathrm{Dar}_{\mathrm{i}, \mathrm{t}}+\beta_{6}$ Tang $_{\mathrm{i}, \mathrm{t}}+$ $B_{7}$ Rugi $_{i, t}+B_{8}$ Dkom $_{i, t}+B_{9}$ Size $_{i, t}+\mu_{i, t}$

KLP = kualitas laporan keuangan yang diukur dengan akrual diskresioner dan diestimasi menggunakan empat model berbeda (model Jones, Model Modified Jones, Model Ball dan Shivakumar dan Model Kasznik). Variabel interaksi KLP*Rule mengukur dampak regulasi pengendalian internal terhadap hubungan antara kualitas laporan keuangan dan inefisiensi investasi (under/over investment). Dalam persamaan (2), $\beta_{1}$ mencerminkan pengaruh kualitas laporan keuangan terhadap inefisiensi investasi (under/over investment) sebelum tahun 2001-2002 dan hasil penjumlahan koefisien utama $\left(\beta_{1}\right)$ dan koefisien interaksi $\left(\beta_{3}\right)$ mencerminkan pengaruh kualitas laporan keuangan terhadap inefisiensi investasi (under/over investment) tahun 2003-2007. Oleh karena itu, jika pengaruh kualitas laporan keuangan terhadap inefisiensi investasi (under/over investment) lebih kuat setelah peraturan pengendalian internal terbit tahun 2003, maka $\beta_{3}$ diprediksi bernilai negatif dan signifikan.
Sementara itu, hipotesis H3a dan H3b memprediksi bahwa perusahaan yang memiliki keterbatasan keuangan melakukan under (over) investment yang lebih kecil setelah regulasi pengendalian internal terbit tahun 2003. Untuk menguji hipotesis ini, perusahaan sampel dibagi ke dalam dua kelompok: perusahaan yang melakukan investasi berlebihan (over investment) dan perusahaan yang sedikit melakukan investasi (under investment). Pengelompokan perusahaan dibahas dengan detail pada bagian pengukuran variabel. Model yang digunakan untuk menguji hipotesis-hipotesis tersebut adalah:

UnderInvi,t (overInvi,t) $=\beta_{0}+\beta_{1}$ Batasi,t $+\beta_{2} \mathrm{KLP}_{\mathrm{i}, \mathrm{t}}+$ $\beta_{2}$ Kasi, $_{i,}+\beta_{4}$ Dari,t $_{i, t}+\beta_{5}$ Tang $_{i, t}+\beta_{6}$ Rugi $_{i,}+$ $B_{7}$ Dkom $_{i, t}+B_{8}$ Size $_{i, t}+\mu_{i, t}$

Variabel Batas adalah variabel dummy yang bernilai 1 jika perusahaan tidak termasuk dalam kelompok perusahaan yang mengalami keterbatasan keuangan, dan 0 jika sebaliknya. Prosedur pengelompokan dibahas dibagian selanjutnya. Hipotesis H3a dan H3b memprediksi perusahaan yang mengalami kesulitan keuangan pada perioda 2003-2007 melakukan under (over) investment yang lebih kecil dibandingkan pada perioda 20012002 .

\section{Pengukuran Variabel}

Inefisiensi investasi merupakan penyimpangan dari tingkat investasi yang diharapkan. Mengikuti Biddle et al. (2009), investasi merupakan fungsi dari pertumbuhan penjualan yang dinyatakan sebagai berikut:

Investment $\mathrm{i}, \mathrm{t}=\beta_{0}+\beta_{1}$ Sales Growth $_{\mathrm{i}, \mathrm{t}-1}+\mu_{\mathrm{it}}$

Dimana Investment ${ }_{i, t}$ merupakan investasi perusahaan i pada tahun t yang diukur dari selisih aset berwujud dan aset tidak berwujud pada tahun $\mathrm{t}$ dibanding tahun $\mathrm{t}-1$ dibagi dengan aset total $\mathrm{t}-1$. Sementara, Sales Growth , $_{\text {, }}$ merupakan persentase pertumbuhan penjualan dari t-2 dan t-1.

Model regresi di atas diestimasi secara crosssectional untuk tiap-tiap tahun dan industri selama perioda 2001-2007. Residual yang diperoleh dari model regresi tersebut mencerminkan penyimpangan dari tingkat investasi ekspektasian dan digunakan sebagai proksi inefisiensi investasi. Residual yang bernilai positif mengindikasikan bahwa perusahaan melakukan investasi secara berlebihan (over investment) dan residual negatif mengindikasikan perusahaan melakukan investasi lebih sedikit (under investment) dari yang seharusnya. Karena inefisiensi investasi bisa disebabkan under/over investment maka variabel ini ditransformasi ke dalam nilai absolut. Jadi, nilai yang lebih tinggi mengindikasian inefisiensi yang 
lebih tinggi pula. Untuk memudahkan interprettasi, variabel under investmentt juga ditransformasi ke dalam nilai absolut. Dengan demikian, semakin tinggi nilainya maka under investment semakin tinggi pula.

Dalam penelitian ini, kualitas laporan keuangan diproksi dengan manajemen laba. Literatur manajemen laba menunjukkan bahwa intervensi manajer terhadap proses pelaporan keaungan dapat dilakukan untuk menaikkan laba (akrual abnormal positif) atau menurunkan laba (akrual abnormal negatif). Semakin tinggi akrual abnormal positif (negatif) maka semakin rendah pula kualitas laba yang dilaporkan. Karena itu akrual abnormal ditransformasi ke dalam nilai absolut dan selanjutnya dikalikan dengan -1 agar lebih mudah diinterpretasikan. Semakin tinggi nilai variabel ini semakin tinggi pula kualitas laporan keuangan. Untuk meningkatkan validitas hasil pengujian hipotesis, akrual abnormal diestimasi menggunakan empat model berbeda: model Jones, model Modified Jones, model Ball dan Shivakumar, dan model kasznik. Keempat model tersebut diestimasi secara cross-sectional untuk tiaptiap industri dan tahun pengamatan. Akrual abnormal merupakan nilai residual yang diperoleh dari selisih antara akrual total dan akrual normal (fitted value). Model pertama yang digunakan untuk mengestimasi akrual diskresioner diambil dari model yang dikembangkan oleh Jones (1991) berikut ini:

$\mathrm{ACCR}_{\mathrm{t}} / \mathrm{TA}_{\mathrm{t}-1}=\alpha_{1}\left(1 / \mathrm{TA}_{\mathrm{t}-1}\right)+\alpha_{2}\left(\Delta \mathrm{SALE}_{\mathrm{t}} \mathrm{TA}_{\mathrm{t}-1}\right)+$

$$
\alpha_{3}\left(\mathrm{PPE}_{\mathrm{t}} / \mathrm{TA}_{\mathrm{t}-1}\right)+\mathrm{et}_{\mathrm{t}}
$$

Untuk alasan kesederhanaan, subskrip untuk perusahaan dan industri dihilangkan. Dalam model di atas, ACCR merupakan akrual total pada tahun t, TAt-1 merupakan aset total pada t-1, $\triangle$ SALEt merupakan perubahan penjualan pada tahun $t$, dan $\mathrm{PPE}_{\mathrm{t}}$ merupakan peralatan, pabrik dan properti pada tahun t. Akrual total diperoleh dari selisih laba sebelum pos-pos ekstraordiner dan operasi yang tidak berlanjut (discontinued operation) dengan arus kas operasi.

Model estimasi kedua yang digunakan adalah model Modified Jones. Model ini merupakan pengembangan model Jones oleh Dechow et al. (1995) dan dinyatakan sebagai berikut: $\mathrm{ACCR}_{\mathrm{t}} / \mathrm{TA}_{, \mathrm{t}-1}=\alpha_{1}\left(1 / \mathrm{TA}_{\mathrm{t}-1}\right)+\alpha_{2}\left(\Delta \mathrm{SALE}_{\mathrm{t}}-\Delta \mathrm{REC}_{\mathrm{t}} / \mathrm{TA}_{\mathrm{t}-}\right.$

$$
\text { 1) }+\alpha_{3}\left(\mathrm{PPE}_{\mathrm{t}} / \mathrm{TA} \mathrm{t}-1\right)+\mathrm{et}_{\mathrm{t}}
$$

Semua variabel didefinisikan dengan cara yang sama seperti model Jones dalam persamaan (5), kecuali $\triangle$ REC yang merupakan selisih piutang pada tahun $t$ dan $t-1$.

Model ketiga untuk mengestimasi akrual diskresioner dikembangkan oleh Ball dan Shivakumar (2005) yang dinyatakan sebagai berikut:

$$
\begin{aligned}
\mathrm{ACCR}_{\mathrm{t} /} / \mathrm{TA}_{\mathrm{t}-1}= & \alpha_{1}\left(1 / \mathrm{TA}_{\mathrm{t}-1}\right)+\alpha_{2}\left(\Delta \mathrm{SALE}_{\mathrm{t}}-\Delta \mathrm{REC}_{\mathrm{t}} / \mathrm{TA}_{\mathrm{t}-}\right. \\
& 1)+\alpha_{3}\left(\mathrm{PPE}_{\mathrm{t}} / \mathrm{TA}_{\mathrm{t}-1}\right)+\alpha_{4}\left(\mathrm{CFO}_{\mathrm{t}} / \mathrm{TA}_{\mathrm{t}-}\right. \\
& 1)+\alpha_{5} \mathrm{D}_{-} \mathrm{CFO}_{\mathrm{t}}+\alpha_{6}\left(\mathrm{CFO}_{t} / \mathrm{TA}_{\mathrm{t}-1}\right)^{*} \\
& \mathrm{D} \_C F O_{\mathrm{t}+}+\mathrm{e}_{\mathrm{t}}
\end{aligned}
$$

Dalam model di atas, semua variabel didefinisikan dengan cara yang sama seperti model Modified Jones kecuali $\mathrm{CFO}_{\mathrm{t}}$ yang merupakan arus kas operasi pada tahun $t$ dan D_CFO merupakan variabel dummy tahun t, 1 jika arus kas operasi bernilai positif dan 0 jika sebaliknya, serta PPE yang merupakan peralatan, pabrik dan properti tahun $\mathrm{t}$.

Model keempat untuk mengestimasi akrual diskresioner dikembangkan oleh Kasznik (1999) yang dinyatakan sebagai berikut:

$\mathrm{ACCR}_{\mathrm{t}} / \mathrm{TA}_{\mathrm{t}-1}=\alpha_{1}\left(1 / \mathrm{TA}_{\mathrm{t}-1}\right)+\alpha_{2}\left(\Delta \mathrm{SALE}_{\mathrm{t}} / \mathrm{TA}_{\mathrm{t}-1}\right)+$ $\alpha_{3}\left(\mathrm{PPE}_{t} / \mathrm{TA}_{\mathrm{t}-1}\right)+\alpha 4\left(\Delta \mathrm{CFO}_{\mathrm{t}} / \mathrm{TA}_{\mathrm{t}-1}\right)+$ $\mathrm{e}_{\mathrm{t}}$

Semua variabel didefinisikan dengan cara yang sama seperti model Ball dan Shivakumar kecuali $\triangle \mathrm{CFO}_{\mathrm{t}}$ yang merupakan selisih arus kas operasi pada tahun t dan t-1.

Variabel Batas merupakan variabel dummy yang diberi kode 1 jika perusahaan tidak mengalami keterbatasan keuangan dan kode 0 jika mengalami masalah keuangan. Menurut Biddle et al. (2009) keterbatasan keuangan ditentukan oleh jumlah kas dan tingkat utang yang dimiliki perusahaan. Perusahaan yang memiliki kas tersedia yang sedikit dan juga memiliki tingkat utang yang tinggi cenderung mengalami masalah keuangan. Prosedur yang digunakan untuk menentukan apakah perusahaan mengalami keterbatasan keuangan adalah sebagai berikut: 1) mengurutkan saldo kas perusahaan dari yang tertinggi hingga terendah. 2) mengurutkan tingkat utang perusahaan (total utang/total aset) dari yang terendah hingga tertinggi. Perusahaan yang memiliki saldo kas dan tingkat utang di atas median merupakan perusahaan yang tidak mengalami keterbatasan keuangan dan diberi kode 1. Sebaliknya, perusahaan yang memiliki saldo kas dan tingkat utang dibawah median merupakan perusahaan yang mengalami keterbatasan keuangan dan diberi kode 0 .

Beberapa variabel yang digunakan dalam penelitian-penelitian terdahulu (Biddle et al. 2009; Cheng et al. 2013; Gomaris dan Balesta 2014 ) dimasukkan kedalam model pengujian hipotesis. Variabel-variabel tersebut adalah: Kas $=$ saldo kas yang dimiliki perusahaan; Dar adalah rasio utang terhadap aset; Tang $=$ rasio aset berwujud terhadap aset total; Rugi = variabel dummy, 1 jika laba negatif dan 0 jika lainnya; Dkom = proporsi dewan komisaris independen yang berada dalam dewan komisaris; Size = ukuran perusahaan yang diukur dengan log aset total. 


\section{Populasi dan Sampel}

Populasi penelitian adalah seluruh perusahaan yang terdaftar di Bursa Efek Indonesia pada tahun 2001-2007. Penelitian ini menggunakan data sekunder yang bersumber dari: 1) Laporan tahunan perusahaan yang dapat diakses malalui situs resmi Bursa Efek Indonesia dengan alamat www.bei.co.id, 2) Indonesian Capital Market Directory (ICMD) edisi 2001-2007 yang diterbitkan oleh Institute for Economic and Financial Research, 3) Pusat Database Pasar Modal Fakultas Ekonomika dan Bisnis Unika Soegijapranata, 4) Situs resmi perusahaan bila data yang diinginkan tidak tersedia dari sumber yang dinyatakan sebelumnya, khususnya informasi mengenai komisaris independen.

Sampel perusahaan yang digunakan adalah perusahaan yang tercatat di Bursa Efek Indonesia, kecuali perbankan dan asuransi, secara berturutturut dari tahun 2001 hingga tahun 2007 dan menyediakan secara lengkap data-data yang digunakan untuk mengukur variabel-variabel penelitian. Tahun 2003 merupakan tahun peristiwa yang menandai terbitnya regulasi pengendalian internal oleh Bapepam-LK. Tahun 2000 tidak dimasukkan sebagai sampel untuk menghindari dampak krisis moneter yang terjadi tahun 1998. Berdasarkan kriteria tersebut, ada 161 perusahaan yang digunakan sebagai sampel dengan 1.127 tahun perusahaan selama perioda sampel 2001-2007. Namun, untuk memenuhi asumsi normalitas jumlah observasi yang digunakan bervariasi untuk tiap-tiap pengujian hipotesis.

\section{HASIL PENELITIAN DAN PEMBAHASAN}

Tabel 1 di bawah ini menampilkan statistik deskriptif variabel-variabel yang digunakan untuk pengujian hipotesis. Dari tabel dapat dilihat bahwa inefisiensi investasi absolut memiliki rata-rata 0,0438 . Ini mengindikasikan bahwa jumlah inefisiensi yang terjadi $4 \%$ dari nilai aset yang dimiliki perusahaan. Nilai ini konsisten dengan hasil riset terdahulu (Gomaris et al. 2014; Chen et al. 2011). Sementara rata-rata over/under investment masing-masing 0,0489 dan 0,0502.

Akrual diskresioner absolut yang telah dikali dengan -1 dan diestimasi menggunakan empat prosedur estimasi yang berbeda memiliki rata-rata masing-masing -0,0954, -0,0671, -0,0522 dan 0,0555 . Artinya, manajemen laba yang dilakukan perusahaan berkisar antara 5\% hingga 9\% dari aset total yang dimiliki perusahaan. Sementara itu, $82,24 \%$ perusahaan sampel tidak mengalami keterbatasan keuangan dan $27,14 \%$ perusahaan sampel mengalami kerugian. Berkaitan dengan variabel kontrol, kas yang tersedia tidak terlalu besar hanya $8,6 \%$ dari aset total dan secara rata- rata perusahaan sampel tidak memiliki tingkat utang yang mengkhawatirkan $(0,648)$. Proporsi dewan komisaris independen yang duduk dalam jajaran dewan komisaris rata-rata sebesar 34,87\% memenuhi persyaratan minimal 30\% yang ditetapkan Bapepam-LK.

Tabel 1. Statistik

\begin{tabular}{lrrrrr}
\hline & N & $\begin{array}{c}\text { Mini- } \\
\text { mum }\end{array}$ & $\begin{array}{c}\text { Maksi- } \\
\text { mum }\end{array}$ & $\begin{array}{c}\text { Rata- } \\
\text { Rata }\end{array}$ & $\begin{array}{c}\text { Deviasi } \\
\text { syandar }\end{array}$ \\
\hline Abs_IneffInv & 1077 & 0,00 & 0,76 & 0,0438 & 0,0671 \\
Abs_Modify & 1087 & $-1,49$ & 0,00 & $-0,0954$ & 0,1155 \\
Abs_Jones & 1087 & $-0,50$ & 0,00 & $-0,0671$ & 0,0616 \\
Abs_Ball & 907 & $-0,33$ & 0,00 & $-0,0522$ & 0,0456 \\
Abs_Kasznik & 894 & -029 & 0,00 & $-0,0555$ & 0,0463 \\
Kas & 1087 & 0,00 & 2,37 & 0,0858 & 0,1515 \\
Dar & 1087 & 0,00 & 5,35 & 0,6480 & 0,5345 \\
Under & 482 & 0,00 & 0,76 & 0,0489 & 0,0684 \\
investment & & & & & \\
Overinvestment & 386 & 0,00 & 0,67 & 0,0502 & 0,0703 \\
Tang & 1087 & 0,00 & 3,15 & 0,4073 & 0,2796 \\
Loss & 1087 & 0,00 & 1,00 & 0,2714 & 0,4448 \\
Dkom & 1087 & 0,00 & 1,00 & 0,3487 & 0,1404 \\
Size & 1087 & 2,75 & 7,91 & 5,8675 & 0,6701 \\
Batas & 1087 & 0,00 & 1,00 & 0,8224 & 0,3821 \\
\hline
\end{tabular}

\section{Deskriptif}

\section{Hasil Analisis Regresi}

Tabel 2 di bawah ini menyajikan hasil regresi persamaan (1) yang menghubungkan kualitas laporan keuangan menggunakan empat prosedur estimasi akrual abnormal yang berbeda dan inefisiensi investasi.

Tabel. 2 Inefisiensi Investasi dan Kualitas Laporan Keuangan perioda 2001-2007.

\begin{tabular}{lcccc}
\hline & 1 & 2 & 3 & 4 \\
\hline KLP_Modify & $-0,674^{* *}$ & & & \\
& $(-2,159)$ & & & \\
KLP_Jones & & $-1,313^{* *}$ & & \\
& & $(-2,271)$ & & $-1,525^{*}$ \\
KLP_B\&S & & & $(-1,914)$ & \\
& & & $-2,066^{* *}$ \\
KLP_Kasz & & & $(-2,565)$ \\
& & & & $-0,404$ \\
Kas & $-0,344$ & $-0,330$ & $-0,430^{*}$ & \\
& $(-1,342)$ & $(-1,376)$ & $(-1,849)$ & $(-1,606)$ \\
Dar & 0,063 & 0,057 & 0,079 & 0,029 \\
& $(0,955)$ & $(0,866)$ & $(1,007)$ & $(0,348)$ \\
Tang & $0,488^{* * *}$ & $0,484^{* * *}$ & 0,127 & $0,360^{* * *}$ \\
& $(3,570)$ & $(3,545)$ & $(0,907)$ & $(2,261)$ \\
Loss & $0,219^{* * * *}$ & $0,208^{* *}$ & $0,207^{* *}$ & $0,242^{* * *}$ \\
& $(2,713)$ & $(2,588)$ & $(2,532)$ & $(2,778)$ \\
Dkom & $0,617^{* *}$ & $0,618^{* * *}$ & $0,440^{* *}$ & 0,363 \\
& $(2,441)$ & $(2,447)$ & $(1,708)$ & $(1,311)$ \\
Size & $-0,036$ & $-0,045$ & 0,023 & $-0,002$ \\
& $(-0,690)$ & $(-0,868)$ & $(0,420)$ & $(-0,027)$ \\
Observasi & 855 & 855 & 766 & 731 \\
\hline
\end{tabular}

*** Signifikan pada 1\%, ** Signifikan pada 5\%, * Signifikan pada $1 \%$ 
Kolom kedua (model 1) menampilkan hasil regresi untuk model Modified Jones yang dikembangkan Dechow et al. (1995), kolom ketiga (model 2) menampilkan hasil regresi model yang dikembangkan Jones (1991), kolom keempat (model 3) menampilkan hasil regresi model Ball dan Shivakumar (2005) dan kolom yang kelima (model 4) menampilkan hasil regresi model yang diusulkan oleh Kasznik (1999). Observasi yang digunkan untuk menguji hipotesis berasal dari tahun 2001-2007 dan sejumlah observasi harus dihilangkan untuk memenuhi asumsi normalitas data. Ada 855 observasi digunakan untuk model 1 dan model 2, 766 observasi digunakan untuk model 3 dan 731 observasi untuk model 4 .

Dari tabel 2 dapat terlihat bahwa seluruh koefisien kualitas laporan keuangan yang diestimasi menggunakan empat model berbeda memiliki nilai negatif dan signifikan pada tingkat 5\% (kecuali model Ball dan Shivakumar yang signifikan pada tingkat 10\%). Hasil ini mengindikasikan bahwa laporan keuangan yang berkualitas dapat menurunkan inefisiensi investasi. Dengan demikian H1 terdukung secara statistis. Hasil ini konsisten dengan yang dilaporkan oleh Biddle et al. (2009), Chen et al. (2011) dan Gomaris dan Balesta (2014).

Tabel 3. Kualitas Laporan Keuangan dan Over investment perioda 2001-2007

\begin{tabular}{|c|c|c|c|c|}
\hline & 1 & 2 & 3 & 4 \\
\hline KLP_Modify & $\begin{array}{c}-1,535^{* *} \\
(-2,455)\end{array}$ & & & \\
\hline KLP_Jones & & $\begin{array}{l}-1,718^{*} \\
(-1,908)\end{array}$ & & \\
\hline KLP_B\&S & & & $\begin{array}{l}-1,304^{*} \\
(-0,883)\end{array}$ & \\
\hline KLP_Kasz & & & & $\begin{array}{c}-3,269 * * \\
(-2,272)\end{array}$ \\
\hline Kas & $\begin{array}{c}-0,007 \\
(-0,022)\end{array}$ & $\begin{array}{c}0,016 \\
(0,053)\end{array}$ & $\begin{array}{l}-0,059^{*} \\
(-0,178)\end{array}$ & $\begin{array}{c}-0,014 \\
(-0,040)\end{array}$ \\
\hline Dar & $\begin{array}{c}0,113 \\
(0,788)\end{array}$ & $\begin{array}{c}0,110 \\
(0,757)\end{array}$ & $\begin{array}{c}-0,018 \\
(-0,094)\end{array}$ & $\begin{array}{l}-0,205 \\
(0,281)\end{array}$ \\
\hline Tang & $\begin{array}{c}1,322^{* * * *} \\
(6,025)\end{array}$ & $\begin{array}{c}1,342^{* * * *} \\
(6,229)\end{array}$ & $\begin{array}{c}0,565^{* * *} \\
(2,535)\end{array}$ & $\begin{array}{c}0,691^{* *} \\
(2,734)\end{array}$ \\
\hline Loss & $\begin{array}{c}-0,037 \\
(-0,283)\end{array}$ & $\begin{array}{c}-0,065 \\
(-0,507)\end{array}$ & $\begin{array}{c}-0,033 \\
(-0,220)\end{array}$ & $\begin{array}{c}0,040 \\
(0,260)\end{array}$ \\
\hline Dkom & $\begin{array}{c}0,755^{* * *} \\
(1,961)\end{array}$ & $\begin{array}{l}0,744^{*} \\
(1,926)\end{array}$ & $\begin{array}{c}0,052 \\
(0,118)\end{array}$ & $\begin{array}{c}-0,092 \\
(-0,198)\end{array}$ \\
\hline Size & $\begin{array}{c}-0,013 \\
(-0,166) \\
411\end{array}$ & $\begin{array}{c}-0,037 \\
(-0,491) \\
412\end{array}$ & $\begin{array}{c}0,0041 \\
(0,441) \\
371\end{array}$ & $\begin{array}{c}0,097 \\
(1,011) \\
374\end{array}$ \\
\hline $\begin{array}{l}\text { KETERANG } \\
\text { uangan yang } \\
\text { KLP_Jones = } \\
\text { dengan mode } \\
\text { keuangan yar } \\
\text { kumar; KLP } \\
\text { diproksi deng } \\
\text { Kas, Dar, Ta } \\
\text { terdapat pada } \\
\text { *** Signifika } \\
\text { fikan pada } 1 \%\end{array}$ & $\begin{array}{l}\text { N: KLP_A } \\
\text { diproksi } \\
\text { zualitas la } \\
\text { Jones; } 1 \\
\text { diproksi } \\
\text { Yasz = ku } \\
\text { a model K } \\
\text { g, Loss, I } \\
\text { abel 1. } \\
\text { pada 1\%; }\end{array}$ & $\begin{array}{l}\text { dify }=\mathrm{k} \\
\text { ngan mo } \\
\text { oran keu } \\
P \_B \& S \\
\text { engan m } \\
\text { itas lapo } \\
\text { znik. Def } \\
\text { om, Size } \\
\text { Signifik }\end{array}$ & $\begin{array}{l}\text { lalitas la } \\
\text { el Modif } \\
\text { ngan yan } \\
=\text { kualita } \\
\text { del Ball c } \\
\text { an keuar } \\
\text { isi varia } \\
\text { sama der } \\
\text { n pada } 5\end{array}$ & $\begin{array}{l}\text { ooran ke- } \\
\text { ed Jones; } \\
\text { g diproksi } \\
\text { s laporan } \\
\text { an Shiva- } \\
\text { gan yang } \\
\text { el kontrol } \\
\text { gan yang } \\
\text {; * Signi- }\end{array}$ \\
\hline
\end{tabular}

Tabel 3 menampilkan hasil regresi yang menguji dampak kualitas laporan keuangan terhadap over investment. Sementara tabel 4 menampilkan hasil regresi yang menguji dampak kualitas laporan keuangan terhadap under investment. Untuk menguji hipotesis tersebut, sampel dibagi ke dalam dua kelompok: perusahaan yang melakukan over investment dan perusahaan yang melakukan under investment. Dari tabel 3 dapat dilihat bahwa kualitas laporan keuangan menurunkan investasi yang berlebihan. Hal ini terindikasi dari koefisien regresi kualitas laporan keuangan dari keempat model yang memiliki arah negatif dan signifikan pada tingkat 5\% (model Dechow dan model Kasznik) dan 10\% (model Jones dan Model Ball dan Shivakumar). Dengan dimikian, H1a terdukung secara statistis. Hasil ini konsisten dengan Biddle et al. (2009) dan Gomaris dan Balesta (2014).

Sementara itu, tabel 4 memperlihatkan bahwa kualitas laporan keuangan tidak berperan signifikan dalam menurunkan under investment. Tidak satupun koefisien regresi dari keempat model yang digunakan signifikan walaupun arahnya sesuai dengan yang diprediksi. Dengan demikian $\mathrm{H}_{1 b}$ tidak terdukung secara statistik dan hasil ini konsisten dengan Gomaris dan Balesta (2014).

Tabel 4. Kualitas Laporan Keuangan dan Under investment Perioda 2001-2007

\begin{tabular}{lcccc}
\hline & 1 & 2 & 3 & 4 \\
\hline KLP_Modify & $-0,264$ & & & \\
& $(-0,694)$ & & & \\
KLP_Jones & & $-0,632$ & & \\
KLP_B\&S & & $(-0,790)$ & $-0,862$ & \\
& & & $(-0,774)$ & $-1,170$ \\
KLP_Kasz & & & & $(-1,101)$ \\
& & & & $-1,482^{* * *}$ \\
Kas & $-0,860^{*}$ & $-0,873$ & $-1,296^{* * *}$ & $-1914)$ \\
& $(-1,779)$ & $(-1,801)$ & $(-2,519)$ & $(-2,914)$ \\
Dar & 0,117 & 0,114 & 0,082 & 0,073 \\
& $(1,459)$ & $(1,417)$ & $(0,827)$ & $(0,743)$ \\
Tang & 0,121 & 0,111 & 0,065 & 0,021 \\
& $(0,544)$ & $(0,500)$ & $(0,279)$ & $(0,090)$ \\
Loss & $0,333^{* * *}$ & 0,328 & 0,310 & $0,266^{* *}$ \\
& $(2,961)$ & $(2,912)$ & $(2,582)^{* *}$ & $(2,266)$ \\
Dkom & $0,704^{*}$ & $0,713^{* *}$ & 0,353 & 0,430 \\
& $(0,052)$ & $(1,971)$ & $(0,913)$ & $(1,123)$ \\
Size & $-0,073$ & $-0,078$ & $-0,037$ & $-0,033$ \\
& $(-0,931)$ & $(-0,993)$ & $(-0,453)$ & $(-0,402)$ \\
Observasi & 444 & 443 & 405 & 357 \\
\hline
\end{tabular}

KETERANGAN: KLP_Modify = kualitas laporan keuangan yang diproksi dengan model Modified Jones; KLP_Jones = kualitas laporan keuangan yang diproksi dengan model Jones; $K L P \_B \& S=$ kualitas laporan keuangan yang diproksi dengan model Ball dan Shivakumar; KLP_Kasz = kualitas laporan keuangan yang diproksi dengan model Kasznik.

*** Signifikan pada $1 \%$; ** Signifikan pada 5\%; * Signifikan pada $1 \%$ 
Seperti yang dibahas dibagian sebelumnya, kualitas laporan keuangan diekspektasi meningkat setelah regulasi pengendalian internal terbit tahun 2003. Apabila kualitas laporan keuangan meningkat seperti yang diprediksi maka inefisiensi investasi (under/over investment) akan menurun. Untuk menguji hipotesis ini, sampel perusahaan dipisah ke dalam dua kelompok yaitu perioda sebelum regulasi 2001-2002 dan perioda saat regulasi berlaku 2003-2007. Variabel Rule ditambahkan ke dalam model untuk memisahkan perioda sebelum dan setelah regulasi. Pengujian hipotesis dampak regulasi terhadap infesiensi investasi (under/over investment) terlihat dari koefisien interaksi KLP*Rule. Tabel 5, Tabel 6 dan Tabel 7 menampilkan hasil analisis regresi.

Dari Tabel 5 dapat dilihat bahwa variabel interaksi antara kualitas laporan keuangan dan perioda regulasi pengendalian internal (KLP*Rule) memiliki arah koefisien negatif dan signifikan pada tingkat 5\% (model Kasznik signifikan pada tingkat 1\%). Seperti yang telah dijelaskan sebelumnya, koefisien interaksi yang bernilai negatif menunjukkan bahwa hubungan antara kualitas laporan keuangan dengan inefisiensi investasi lebih kuat setelah regulasi pengendalian internal terbit tahun 2003 dibandingkan perioda sebelumnya. Dengan demikian, H2 terdukung secara statistis. Namun yang menarik adalah hubungan antara kualitas laporan keuangan dan inefisiensi investasi (under/over investment) tidak signifikan pada perioda 2001-2002 (sebelum regulasi terbit). Ini dapat terlihat dari tabel 5 bahwa tidak satupun variabel kualitas laporan keuangan dari keempat model signifikan pada tingkat $10 \%$. Hasil ini mengindikasikan bahwa laporan keuangan tidak berperan dalam menurunkan kecenderungan perusahaan untuk melakukan investasi secara berlebihan atau menurunkan kecenderungan untuk berinvestasi terlalu sedikit pada perioda sebelum regulasi pengendalian internal terbit.

Walaupun sedikit berbeda, secara umum hasil regresi yang menguji dampak kualitas laporan keuangan terhadap over investment yang ditampilkan pada tabel 6 mendukung pentingnya laporan keuangan yang berkualitas dalam menurunkan inefisiensi investasi. Seperti yang telah dijelaskan sebelumnya, peningkatan laporan keuangan menyusul terbitnya regulasi pengendalian internal diprediksi menurunkan over investment. Koefisien regresi variabel interaksi seluruh model (kecuali model Dechow) memiliki arah negatif dan signifikan pada tingkat 5\%. Dengan demikian $\mathrm{H}_{2 \mathrm{a}}$ terdukung secara statistis.
Tabel 5. Regulasi Pengendalian Internal dan Inefisiensi Investasi Perioda 2001-2007

\begin{tabular}{|c|c|c|c|c|}
\hline & 1 & 2 & 3 & 4 \\
\hline$\overline{\text { KLP_Modify }}$ & $\begin{array}{c}0,001 \\
(0,003)\end{array}$ & & & \\
\hline KLP_Jones & & $\begin{array}{c}0,705 \\
(0,767)\end{array}$ & & \\
\hline KLP_B\&S & & & $\begin{array}{c}0,863 \\
(0,719)\end{array}$ & \\
\hline KLP_Kasz & & & & $\begin{array}{c}1,035 \\
(0,812)\end{array}$ \\
\hline Rule & $\begin{array}{c}-0,086 \\
(-1,010)\end{array}$ & $\begin{array}{c}-0,111 \\
(-0,951)\end{array}$ & & $\begin{array}{c}-0,267 \\
(-2,132)\end{array}$ \\
\hline KLP_Modify*Rule & $\begin{array}{c}-1,151^{* * *} \\
(-1,989)\end{array}$ & & & \\
\hline KLP_Jones*Rule & & $\begin{array}{c}-2,872^{* *} \\
(-2,403)\end{array}$ & & \\
\hline KLP_B\&S*Rule & & & $\begin{array}{c}-3,085^{* *} \\
(-2,066)\end{array}$ & \\
\hline KLP_Kasz*Rule & & & & $\begin{array}{c}-5,033^{* * * *} \\
(-3,106)\end{array}$ \\
\hline Kas & $\begin{array}{c}-0,155 \\
(-0,721)\end{array}$ & $\begin{array}{c}-0,350 \\
(-1,372)\end{array}$ & $\begin{array}{c}-0,601^{* * *} \\
(-2,659)\end{array}$ & $\begin{array}{l}-0,501 * * \\
(-1,991)\end{array}$ \\
\hline Dar & $\begin{array}{c}0,085 \\
(1,545)\end{array}$ & $\begin{array}{c}0,102 \\
(1,461)\end{array}$ & $\begin{array}{c}0,065 \\
(0,896)\end{array}$ & $\begin{array}{c}0,036 \\
(0,433)\end{array}$ \\
\hline Tang & $\begin{array}{c}0,125 \\
(0,962)\end{array}$ & $\begin{array}{c}0,572^{* * *} \\
(3,976)\end{array}$ & $\begin{array}{c}-0,124 \\
(-0,945)\end{array}$ & $\begin{array}{c}0,366^{* *} \\
(2,321)\end{array}$ \\
\hline Loss & $\begin{array}{c}0,174^{* *} \\
(2,540)\end{array}$ & $\begin{array}{c}0,188^{* *} \\
(2,227)\end{array}$ & $\begin{array}{c}0,230 * * * * \\
(3,015)\end{array}$ & $\begin{array}{c}0,221^{* *} \\
(2,539)\end{array}$ \\
\hline Dkom & $\begin{array}{l}0,392^{*} \\
(1,784)\end{array}$ & $\begin{array}{c}0,740^{* * *} \\
(2,736)\end{array}$ & $\begin{array}{l}0,174^{*} \\
(0,711)\end{array}$ & $\begin{array}{c}0,419 \\
(1,500)\end{array}$ \\
\hline Size & $\begin{array}{c}-0,038 \\
(-0,856)\end{array}$ & $\begin{array}{c}-0,039 \\
(-0,709)\end{array}$ & $\begin{array}{c}0,020 \\
(0,408)\end{array}$ & $\begin{array}{c}0,016 \\
(0,279)\end{array}$ \\
\hline Observasi & 760 & 884 & 680 & 734 \\
\hline
\end{tabular}

Tabel 6. Regresi Pengendalian Internal dan Over Investment Perioda 2001-2007

\begin{tabular}{|c|c|c|c|c|}
\hline & 1 & 2 & 3 & 4 \\
\hline KLP_Modify & $\begin{array}{c}0,214 \\
(0,188)\end{array}$ & & & \\
\hline KLP_Jones & & $\begin{array}{c}1,278 \\
(0,887)\end{array}$ & & \\
\hline KLP_B\&S & & & $\begin{array}{c}3,096 \\
(1,274)\end{array}$ & \\
\hline KLP_Kasz & & & & $\begin{array}{c}0,868 \\
(0,399)\end{array}$ \\
\hline Rule & $\begin{array}{c}-0,134 \\
(-0,780)\end{array}$ & $\begin{array}{c}-0,223 \\
(-1,265)\end{array}$ & & $\begin{array}{c}-0,268 \\
(-1,449)\end{array}$ \\
\hline KLP_Modify*Rule & $\begin{array}{c}-1,659 \\
(-1,228)\end{array}$ & & & \\
\hline KLP_Jones*Rule & & $\begin{array}{c}-4,116^{* *} \\
(-2,197)\end{array}$ & & \\
\hline KLP_B\&S*Rule & & & $\begin{array}{c}-6,712^{* *} \\
(-2,142)\end{array}$ & \\
\hline KLP_Kasz*Rule & & & & $\begin{array}{c}-5,340^{* *} \\
(-1,990)\end{array}$ \\
\hline Kas & $\begin{array}{c}-0,083 \\
(-0,267) \\
\end{array}$ & $\begin{array}{c}-0,170 \\
(-0,539) \\
\end{array}$ & $\begin{array}{c}-0,160 \\
(-0,449) \\
\end{array}$ & $\begin{array}{c}-0,082 \\
(-0,268) \\
\end{array}$ \\
\hline
\end{tabular}




\begin{tabular}{lcccc}
\hline & 1 & 2 & 3 & 4 \\
\hline Dar & 0,080 & 0,005 & $-0,220$ & 0,112 \\
& $(0,485)$ & $(0,030)$ & $(-0,972)$ & $(0,537)$ \\
Tang & $1,103^{* * *}$ & $0,961^{* * *}$ & $0,624^{* * *}$ & $0,794^{* * *}$ \\
& $(5,355)$ & $(4,838)$ & $(2,632)$ & $(3,469)$ \\
Loss & $-0,087^{* * *}$ & $-0,045$ & $-0,010$ & $-0,063$ \\
& $(-0,631)$ & $(-0,327)$ & $(-0,062)$ & $(-0,456)$ \\
Dkom & 0,657 & 0,582 & $-0,019$ & 0,426 \\
& $(1,629)$ & $(1,425)$ & $(-0,040)$ & $(0,999)$ \\
Size & 0,006 & 0,014 & 0,135 & 0,013 \\
& $(0,074)$ & $(0,173)$ & $(1,344)$ & $(0,153)$ \\
Observasi & 421 & 424 & 379 & 355 \\
\hline
\end{tabular}

Tabel 7. Regulasi Pengendalian Internal dan Under investment Perioda 2001-2007

\begin{tabular}{|c|c|c|c|c|}
\hline & 1 & 2 & 3 & 4 \\
\hline$\overline{\mathrm{KLP}}$ _Modify & $\begin{array}{c}-0,238 \\
(-0,384)\end{array}$ & & & \\
\hline KLP_Jones & & $\begin{array}{c}0,148 \\
(0,117)\end{array}$ & & \\
\hline KLP_B\&S & & & $\begin{array}{c}0,056 \\
(0,066)\end{array}$ & \\
\hline KLP_Kasz & & & & $\begin{array}{c}1,420 \\
(0,821)\end{array}$ \\
\hline Rule & $\begin{array}{c}0,082 \\
(0,595)\end{array}$ & $\begin{array}{c}-0,030 \\
(-0,850)\end{array}$ & & $\begin{array}{c}-0,253 \\
(-1,351)\end{array}$ \\
\hline KLP_Modify*Rule & $\begin{array}{c}-0,082 \\
(-0,105)\end{array}$ & & & \\
\hline KLP_Jones*Rule & & $\begin{array}{c}-1,535 \\
(-0,945)\end{array}$ & & \\
\hline KLP_B\&S*Rule & & & $\begin{array}{c}-1,203 \\
(-0,820)\end{array}$ & \\
\hline KLP_Kasz*Rule & & & & $\begin{array}{l}-4,266^{*} \\
(-1,927)\end{array}$ \\
\hline Kas & $\begin{array}{c}-0,739 \\
(-1,467)\end{array}$ & $\begin{array}{l}-0,859^{*} \\
(-1,711)\end{array}$ & $\begin{array}{c}-1,267^{* *} \\
(-2,376)\end{array}$ & $\begin{array}{c}-1,443^{* * *} \\
(-2,714)\end{array}$ \\
\hline Dar & $\begin{array}{c}0,106 \\
(1,185)\end{array}$ & $\begin{array}{c}0,116 \\
(1,279)\end{array}$ & $\begin{array}{c}0,061 \\
(0,537)\end{array}$ & $\begin{array}{c}0,036 \\
(0,313)\end{array}$ \\
\hline Tang & $\begin{array}{c}0,117 \\
(0,523)\end{array}$ & $\begin{array}{c}0,130 \\
(0,576)\end{array}$ & $\begin{array}{c}0,055 \\
(0,232)\end{array}$ & $\begin{array}{c}0,023 \\
(0,095)\end{array}$ \\
\hline Loss & $\begin{array}{c}0,332^{* * * *} \\
(2,911)\end{array}$ & $\begin{array}{c}0,331^{* * * *} \\
(2,894)\end{array}$ & $\begin{array}{c}0,319^{* *} \\
(2,314)\end{array}$ & $\begin{array}{c}0,317^{* * * *} \\
(2,609)\end{array}$ \\
\hline Dkom & $\begin{array}{l}0,638^{*} \\
(1,717)\end{array}$ & $\begin{array}{l}0,695^{*} \\
(1,852)\end{array}$ & $\begin{array}{c}0,336 \\
(0,852)\end{array}$ & $\begin{array}{c}0,342 \\
(0,859)\end{array}$ \\
\hline Size & $\begin{array}{c}-0,074 \\
(-0,933)\end{array}$ & $\begin{array}{c}-0,073 \\
(-0,932)\end{array}$ & $\begin{array}{c}-0,033 \\
(-0,393)\end{array}$ & $\begin{array}{c}-0,022 \\
(-0,262)\end{array}$ \\
\hline Observasi & 470 & 471 & 396 & 391 \\
\hline
\end{tabular}

Pengaruh kualitas laporan keuangan dan under investment ditampilkan pada tabel 7. Semua koefisien interaksi kualitas laporan keuangan dan regulasi menunjukkan arah negatif. Namun, hanya model Kasznik yang signifikan pada tingkat $10 \%$. Hasil ini mengindikasikan bahwa kualitas laporan keaungan tidak berperan penting dalam menurunkan inefisiensi investasi yang bersumber dari under investment. Dengan demikian $\mathrm{H} 2 \mathrm{~b}$ tidak terdukung secara statistis.
Kecenderungan perusahaan melakukan investasi secara berlebihan atau investasi yang terlalu kecil dapat dipengaruh oleh sumber keuangan perusahaan. Seperti yang di jelaskan sebelumnya, kesenjangan informasi antara manajer dan pihak luar mendorong perusahaan yang memiliki kas melimpah dan tingkat utang yang rendah melakukan secara tidak terkendali (over investment). Sebaliknya, perusahaan yang memiliki tingkat utang tinggi dan kas yang kecil akan cenderung menahan diri untuk melakukan investasi, walaupun proyek tersebut memberikan net present value positif (under invesment). Hipotesis $\mathrm{H}_{3 a}$ dan $\mathrm{H}_{3 b}$ memprediksi bahwa setelah regulasi pengendalian internal terbit kecenderungan perusahaan yang memiliki keterbatasan keuangan untuk melakukan over/under investment menurun.

Tabel 8 menampilkan hasil regresi yang mengaitkan antara keterbatasan keuangan dan over/under investment. Untuk menguji perbedaan tingkat over/under investment sebelum dan setelah regulasi terbit tahun 2003, variabel Batas yang merupakan variabel dummy (1 jika perusahaan mengalami keterbatasan keuangan dan 0 jika tidak) dimasukkan ke dalam model. Dengan alasan simplisitas, tabel 8 hanya menampilkan model estimasi menggunakan model Kasznik. Walaupun tidak dilaporkan, hasil pengujian menggunakan tiga model estimasi akrual abnormal lainnya secara kualitatif menunjukkan hasil yang sama.

Tabel 8. Keterbatasan Keuangan dan Under (Over) Investment Perioda 2001-2007

\begin{tabular}{|c|c|c|c|c|}
\hline & Over & vestment & Under & vestment \\
\hline & Koefis & $t$ & Koefisi & $t$ \\
\hline Batas & $-0,080$ & $-0,398$ & $-0,075$ & $-0,487$ \\
\hline KLP_Kasz & $-2,842$ & $-2,056^{* *}$ & $-1,033$ & $-0,957$ \\
\hline Kas & 0,032 & 0,096 & $-1,344$ & $-2,569 * *$ \\
\hline Dar & $-0,063$ & $-0,289$ & 0,046 & 0,412 \\
\hline Tang & 0,671 & $2,735^{* * *}$ & 0,005 & 0,020 \\
\hline Loss & $-0,023$ & $-0,156$ & 0,289 & $2,046^{* *}$ \\
\hline Dkom & 0,087 & 0,195 & 0,308 & 0,791 \\
\hline Size & 0,045 & 0,476 & $-0,035$ & $-0,426$ \\
\hline Observasi & & 67 & & 95 \\
\hline $\mathrm{F}$ & & 69 & & 54 \\
\hline
\end{tabular}

Dari tabel 8 dapat dilihat bahwa koefisien Batas tidak signfikan secara statistis. Hasil ini mengindikasikan bahwa tidak ada perbedaan tingkat over/under investment sebelum dan setelah regulasi pengendalian internal terbit. Dengan demikian, hipotesis H3a dan H3b tidak terdukung secara statistis. 


\section{KESIMPULAN}

Hasil-hasil studi terdahulu menunjukkan bahwa pengendalian internal yang baik dapat meningkatkan kualitas laporan keuangan dan menurunkan inefisiensi investasi. Studi ini menguji pengaruh kualitas laporan keuangan dengan mengambil konteks terbitnya regulasi pengendalian internal tahun 2003. Dengan menggunakan sampel yang terdaftar di BEI tahun 2001-2007, hasil analisis regresi menunjukkan bahwa laporan keuangan yang berkualitas menurunkan inefisiensi investasi. Namun, hasil pengujian yang memisahkan sampel ke dalam perioda 2001-2002 (sebelum regulasi) dan 2003-2007 (setelah regulasi) memperlihatkan bahwa sebelum regulasi pengendalian internal diterbitkan kualitas laporan keuangan tidak berpengaruh terhadap inefisiensi investasi. Sebaliknya, hasil regresi menggunakan sampel perioda 2003-2007 menunjukkan kualitas laporan keuangan berhubungan negatif signifikan terhadap inefisiensi investasi. Hasil ini menunjukkan kualitas laporan keuangan meningkat pasca regulasi terbit.

Pengujian lanjutan dengan memisahkan perusahan sampel ke dalam kondisi under investment dan over investment menunjukkan bahwa kualitas laporan keuangan menurunkan under investment dan over investment. Hasil regresi juga menunjukkan bahwa over investment mengalami penurunan pada perioda 2003-2007. Namun hal yang berbeda terjadi pada under investment. Penurunan under investment tidak terjadi pada perioda 2003-2007. Secara keseluruhan hasil-hasil yang ditemukan menunjukkan bahwa laporan keuangan berperan penting dalam menurunkan inefisiensi investasi yang diakibatkan oleh over investment. Berkaitan dengan keterbatasan sumber keuangan, hasil regresi menunjukkan bahwa tingkat under investment dan over investment tidak berbeda pada perioda 2001-2002 dan 2003-2007.

\section{DAFTAR PUSTAKA}

Abel, A. (1983), Optimal investment under uncertainty, American Economic Review 73, 228233.

Altamuro, J., and Beatty, A. (2010), How does Internal Control Regulation Affect Financial Reporting?, Journal of Accounting and Economics 49,58-74.

Arens, A.A., R.J. Elder., and Beasley, M.S. (2012). Auditing and Assurance Services: An Integrated Approach. Fourteenth Edition. Pearson

Ashbaugh-Skaife, H., Collins, D., Kinney, W., and LaFond, R., (2008), Internal control deficiencies, remediation and accrual quality, The Accounting Review 83 (1), 217-250.
Ayers, B; Jiang. J; and Yeung, P. (2006), Discretionary Accruals and Earnings Management: An Analysis of Pseudo Earnings Targets, The Accounting Review 81: 617-652.

Ball, R., and Shivakumar, L. (2006), Earnings Quality in UK Private Firms: Comparative Loss Recognition Timeliness, Journal of Accounting and Economics 39, 83-128.

Biddle, G., Hilary, G., and Verdy R.S. (2009), How Does Financial Reporting Quality Relate to Investment Efficiency?, Journal of Accounting and Economics 48, 112-131.

Blanchard, O., Lopez-de-Silanez, F., and Shleifer, A. (1994), What do Firms do With Cash Windfalls?, Journal of Financial Economics 36, 337-360.

Chen, F., Hope, O., Li, Q., and Wang, X. (2011), Financial Reporting Quality and Investment Efficiency of Private Firms in Emerging Markets, The Accounting Review 86, 1255-1288.

Cheng, M; Dhaliwal, D; and Zhang Y. (2013), Does Investment Efficiency Improve After the Disclosure of Material Weakness in Internal Control over Financial Reporting?, Journal Of Accounting and Economics 56: 1-18.

Dechow, P. (1994), Accounting Earnings and Cash Flows as Measures of Firm Performance: The Role of Accounting Accruals, Journal of Accounting and Economics 18: 3-42

P., Sloan, R., and Sweeney, A. (1995), Detecting Earnings Management, The Accounting Review 70, 193-225.

Doyle, J., Ge, W., and McVay, S. (2007), Accruals Quality and Internal Control Over Financial Reporting, The Accounting Review 82, 11411170

Feng, M., Li, C., and McVay, S. (2009), Internal Control and Management Guidance, Journal of Accounting and Economics 48,190-209.

Gomaris, M.F.C. and Ballesta, J.P.S. (2014), Financial Reporting Quality, Debt Maturity, and Investment Efficiency, Journal of Bangking and Finance 40: 494-506.

Jensen, M. (1986), Agency Costs of Free Cash Flow, Corporate Finance, and Takeovers, American Economic Review 76, 323-329.

Jensen, M.C. and Meckling, W.H. (1976), Theory of The Firm: Managerial Behavior, Agency Costs and Ownership Structure, Journal of Financial Economics. 10, 305-360.

Jones, J. (1991), Earnings Management During Import Relief Investigation, Journal of Accounting Research 29: 193-228.

Kasznik, R. (1999), On The Association Between Voluntary Disclosure and Earnings management, Journal of Accounting Research 37, 5781. 
Lambert, R., Leuz, C., and Verrecchia, R. (2007), Accounting Information, Disclosure, and The Cost of Capital, Journal of Accounting Research 45, 385-420.

Myers, S., and Majluf, N. (1984), Corporate Financing and Investment Decisions When
Firms Have Information That Investors Do Not Have, Journal of Financial Economics 13, 187-221.

Watts, R., and Zimmerman, J. (1986), Positive Accounting Theory. Engelwood Cliffs, NJ: Prentice Hall. 